\title{
Thermally Treated Clay as a Stabilizing Agent for Expansive Clayey Soil: Some Engineering Properties
}

https://doi.org/10.2478/sgem-2018-0025

received July 23, 2018; accepted October 4, 2018.

Abstract: The objective of this research was to investigate the effect of adding thermally treated clay on some engineering properties of the untreated expansive clayey soil. Three expansive clayey soil samples obtained from three different sites in the south of Syria have been investigated. They were thermally treated up to three different levels $\left(450^{\circ} \mathrm{C}, 650^{\circ} \mathrm{C}\right.$ and $\left.850^{\circ} \mathrm{C}\right)$ for 3 hours. Three replacement levels of thermally treated clay were used, i.e. $0 \%, 10 \%$ and $20 \%$. The X-ray diffractometer (XRD) technique has been used to detect the crystalline and glassy phase in the clayey samples before and after the thermal treatment. Pozzolanic activity of the thermally treated clayey soil has been studied using the modified Chapelle test and the mechanical strength test at each of the temperature levels. Atterberg limits, compaction, free swell, swelling pressure and linear shrinkage have particularly been investigated. Test results revealed the positive effect of thermally treated clay when added to the natural soil. Plasticity index (PI) was reduced by about $60 \%$ when $20 \%$ thermally treated clay was added to the natural soil. In addition, $6 \%$ lime was added to further investigate the combined effect of lime and calcined clay on the properties of the clayey expansive soil. All investigated properties were significantly improved when $20 \%$ thermally treated soil and 6\% lime were added together. For instance, swelling pressure and linear shrinkage values were reduced to less than $15 \%$ or even much less when compared with those of the natural soil. Scanning electron microscopy (SEM) and energydispersive X-ray (EDX) analysis were employed as well.

\footnotetext{
*Corresponding author: Aref M. Al-Swaidani, Faculty of Architectural Engineering, Arab International University, Damascus, Syria, E-mail: aydlswaidan@gmail.com

Ibraheem Hamood, Ayman Meziab: Department of Geotechnical Engineering, Faculty of Civil Engineering, Damascus University, Damascus, Syria; Faculty of Architectural Engineering, Arab International University, Damascus, Syria
}

Keywords: thermally treated clay; soil improvement; plasticity index; linear shrinkage.

\section{Introduction}

Expansive clayey soil has problematic properties. Many additives have been used to stabilize the clayey soil. Lime is considered the oldest stabiliser for clayey soil [1]. Three forms of lime have widely been used: quicklime (calcium oxide - $\mathrm{CaO}$ ), hydrated lime (calcium hydroxide - $\left.\mathrm{Ca}(\mathrm{OH})_{2}\right)$ and hydrated lime slurry [2]. Many researchers reported the positive combined effect of adding lime and mineral admixtures on the stabilization of expansive clayey soil [3-6]. In the study of Al-Swaidani et al. [6], lime and natural pozzolan were added to soil within the range of $0 \%-8 \%$ and $0 \%-20 \%$, respectively. Their test results revealed that the plasticity index (PI) decreased from $29 \%$ to $3 \%$ when $8 \%$ lime and $20 \%$ natural pozzolan were added to the investigated clayey soil. This improvement moved the soil class from $\mathrm{CH}$ to $\mathrm{ML}$, which rendered the soil satisfactory for most construction purposes. In addition, adding the same combination has reduced the linear shrinkage index from $16 \%$ to less than $4.2 \%$, which may be considered non-problematic [6].

In Syria, a wide area is covered by clayey soils. They occupy an area of about $12 \%$ of the country [6]. They cause serious damage to infrastructure. Therefore, there will be a growing need for stabilized clayey soil in the future, particularly in the reconstruction stage in Syria. The paper recently published by the same authors [6] was the motivation for this work.

EN197-1:2000 [7] describes natural calcined pozzolans as materials of volcanic origin, clays, shales or sedimentary rocks, activated by thermal treatment, and shall conform the properties of pozzolanic materials. Calcined clay has widely been used as cement replacement [8-12]. However, the authors believe that very little work or even no detailed work on using calcined clay as a soil stabilizing agent were found in the literature.

This paper aims to study the effect of adding thermally treated clay on the properties of the natural soil 
Table 1: Basic properties of the studied clayey soils.

\begin{tabular}{llllllll}
\hline Soil & $\begin{array}{l}\text { Depth } \\
(\mathbf{m})\end{array}$ & $\begin{array}{l}\text { Specific gravity, Clay particles, } \\
\boldsymbol{P}\left(\mathbf{g} / \mathbf{c m}^{3}\right)\end{array}$ & $\begin{array}{l}\text { Plasticity index } \\
\boldsymbol{d}<\mathbf{0 . 0 0 2} \mathbf{~ m m}\end{array}$ & $\begin{array}{l}\text { Soil classification } \% \\
(\text { USCS) }[13]\end{array}$ & $\begin{array}{l}\text { Optimum water } \\
\text { content, } \boldsymbol{w}_{\text {ont }}(\%)\end{array}$ & $\begin{array}{l}\text { Maximum dry unit } \\
\text { weight, } \gamma_{\text {dmax }}\left(\mathbf{g} / \mathbf{c m}^{3}\right)\end{array}$ \\
\hline S1 & 1 & 2.69 & 23 & 29 & $\mathrm{CH}$ & 25.5 & 1.42 \\
S2 & 0.75 & 2.67 & 31.5 & 35 & $\mathrm{CH}$ & 23 & 1.38 \\
S3 & 1.25 & 2.72 & 35 & 42 & $\mathrm{CH}$ & 26 & 1.30 \\
\hline
\end{tabular}

Table 2: Some physical properties with chemical composition of quick lime.

\begin{tabular}{|c|c|c|c|c|c|c|}
\hline \multicolumn{4}{|c|}{ Chemical composition (\%) } & \multicolumn{3}{|c|}{ Physical properties } \\
\hline $\mathrm{CaO}$ & $\mathrm{MgO}$ & $\mathrm{Fe}_{2} \mathrm{O}_{3}$ & Sulphates $\left(\mathrm{SO}_{4}\right)$ & $\begin{array}{l}\text { Loss of ignition } \\
\text { (\%) }\end{array}$ & $\begin{array}{l}\text { Specific gravity } \\
\left(\mathrm{g} / \mathrm{cm}^{3}\right)\end{array}$ & $\begin{array}{l}\text { Blaine fineness } \\
\left(\mathrm{cm}^{2} / \mathrm{g}\right)\end{array}$ \\
\hline 93.5 & 0.53 & 0.47 & 1.2 & 3.9 & 2.2 & 4000 \\
\hline
\end{tabular}

when added at three replacement levels: $0 \%, 10 \%$ and $20 \%$. Atterberg limits, compaction, free swell, swelling pressure and linear shrinkage have particularly been investigated. In all, $6 \%$ lime content was added to each of the prepared clayey mixes to investigate the combined effect of lime and calcined clay on the studied properties. The X-ray diffractometer (XRD) technique was used to identify the modification of clay structure caused by the thermal treatment. The study can be useful for other areas of similar geology such as Harrat Al-Shaam, which covers parts of KSA, Jordan and Syria. Furthermore, the study is of a great importance in the rebuilding stage in Syria.

\section{Materials and methods}

\subsection{Materials}

\subsubsection{Natural clayey soil}

Three different soil samples obtained from three different sites in the south of Syria were investigated. Table 1 lists some basic properties of the studied clay samples.

\subsubsection{Lime}

Quick lime quarried from Hama Governance was used in the experiments. It was calcined at $950^{\circ} \mathrm{C}$. Some physical properties with chemical composition of lime are shown in Table 2.

\subsubsection{Thermally treated clay}

The extracted soil samples were thermally treated at three different temperatures: $450^{\circ} \mathrm{C}, 650^{\circ} \mathrm{C}$ and $850^{\circ} \mathrm{C}$, respectively, for 3 hours.

\subsubsection{Clay mixtures}

Eighteen clay mixtures were prepared (six for each clay soil). Table 3 shows the mixture ingredient contents in percentage. The mixtures were designated according to the replacement level. For instance, CC2OL6 and CC10L0 refer to clay mixture containing $20 \%$ thermally treated clay and $6 \%$ lime and 20\% thermally treated clay and $0 \%$ lime, respectively. All replacement levels were made by mass on a dry basis.

\subsection{Methods}

A series of laboratory tests has been conducted on the investigated clayey soils. It can be summarized as follows:

i) XRD analysis: This technique was used to explore the different phases in the treated clayey soils. The absence of a peak in the diagram is considered as an evidence that the modification into glassy phase or melting took place. SATOE STADI XRD using CuK $\alpha$ radiation, operated at $40 \mathrm{KV}$ and $30 \mathrm{~mA}$ with a scan mode ranging from $5^{\circ}$ to $70^{\circ}$, and a scan speed of $2^{\circ} \%$ min was were employed used in this analysis

ii) Measurement of the pozzolanic activity of the thermally treated clayey samples: 
Table 3: Clay mixtures used in the study.

\begin{tabular}{|c|c|c|c|}
\hline \multirow[t]{2}{*}{ Clay mixture } & \multicolumn{3}{|c|}{ Percentage } \\
\hline & Clay soil & Thermally treated clay & Lime \\
\hline CCOLO (control) & 100 & 0 & 0 \\
\hline CCOL6 & 94 & 0 & 6 \\
\hline CC10L0 & 90 & 10 & 0 \\
\hline CC2OLO & 80 & 20 & 0 \\
\hline CC10L6 & 84 & 10 & 6 \\
\hline CC20L6 & 74 & 20 & 6 \\
\hline
\end{tabular}

The pozzolanic activity was determined by two techniques:

a) The first technique used was the modified Chapelle test (Figure 1). This test was carried out in accordance with NF P18-513 [14].

b) The second one used was the mechanical test method, which was carried out on cubic mortar samples prepared by mixing the treated clay with lime and standard sand (Figure 2). These samples were tested after three different curing times, i.e. 2, 7 and 28 days, respectively.

iii) Atterberg limits (liquidity limit (LL), plasticity limit and PI) were measured in accordance with ASTM D4318 [15]. The test was carried out at room temperature.

iv) Maximum dry unit weight $\left(\gamma_{\text {dmax }}\right)$ and optimum water content $\left(W_{\text {opt }}\right)$ of the investigated soils were determined using a standard proctor compaction test conducted in accordance with ASTM D698 [16]. The mixtures were prepared by mixing the air-dried clayey soil samples with different percentages of thermally treated clay and 6\% lime. Distilled water was used in the mixtures. The soil mixtures, with or without additives, were thoroughly mixed for $1 \mathrm{~h}$ prior to compaction.

v) Free swelling and swelling pressure of the soil mixtures were measured using the oedometer device in accordance with ASTM D4645 [17] and ASTM D2435 [18]. The samples were compacted in the ring of the oedometer device according to the maximum dry unit weight $\left(\gamma_{\text {dmax }}\right)$ and optimum water content $\left(W_{\text {opt }}\right)$ obtained from the standard proctor compaction test. Distilled water was added to the oedometer cell to start the test. Deformation readings were recorded at 1, 2, 4, 8, 15 and 30 minutes and at 1, 2, 4, 8, 24, 48, 72 and 96 hours. Vertical pressures of 5, 10, 20, 40 and $80 \mathrm{kPa}$ were applied on each sample.

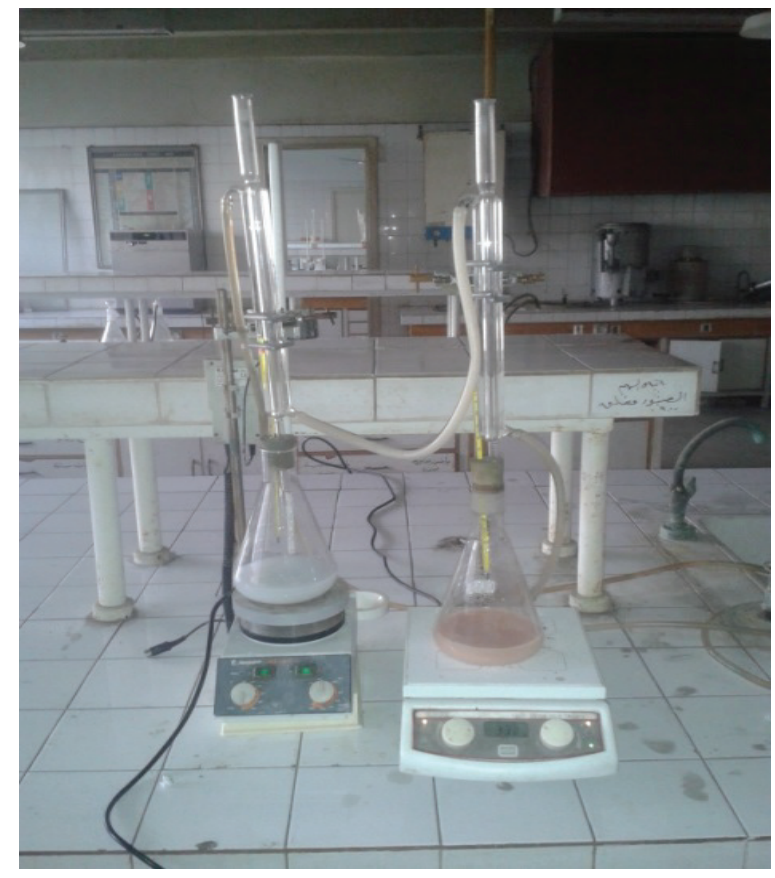

Figure 1: Photograph of the modified Chapelle test set-up.

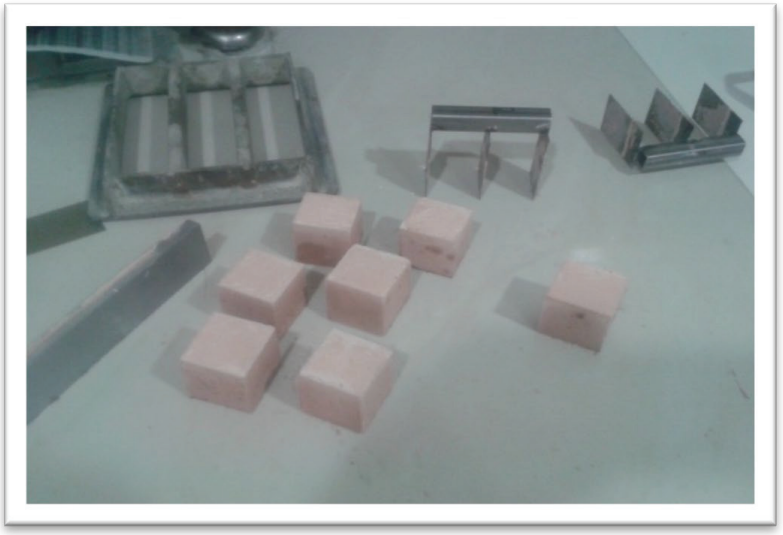

Figure 2: Photograph of $4^{\prime} 4^{\prime} 4 \mathrm{~cm}^{3}$ clay mortar cubes prepared by mixing the clayey soil thermally treated at $850^{\circ} \mathrm{C}$ for 3 hours, lime and standard sand.

vi) Linear shrinkage was determined using the bar linear shrinkage test conducted in accordance with BS 1377 [19]. A quantity of about $150 \mathrm{~g}$ of the soil sample passing No. 40 sieve was mixed with distilled water, approximately $2 \%$ above the LL of each soil mixture The thoroughly mixed soil water paste was placed in the shrinkage mould and then gently jarred to remove any air pockets in the paste. Drying mould first started at a temperature of about $60^{\circ} \mathrm{C}-65^{\circ} \mathrm{C}$ until shrinkage has largely ceased and then was completed at $105^{\circ} \mathrm{C}-$ $110^{\circ} \mathrm{C}$. 
The linear shrinkage index $\left(L_{\mathrm{SI}}\right)$ of the soil was calculated using the following formula [6]:

$$
L_{\mathrm{SI}}(\%)=1-L_{\mathrm{avg}} / L_{\mathrm{O}}
$$

where $L_{\text {avg }}$ is the average length of the oven-dry sample $(\mathrm{mm})$ and $L_{0}$ is the original length of brass mould ( $\mathrm{mm}$ ).

\section{Results and discussion}

\subsection{XRD analysis}

The results of XRD analysis for the investigated three soils before and after the thermal treatment are illustrated in Figures 3-5. As clearly shown in Figures $3-5$, the investigated soils consist of clay and non-clay minerals. The main clay minerals were kaolinite, illite and montmorillonite. Quartz, feldspar and calcite as non-clay minerals were detected as well. The thermal treatment up to $450^{\circ} \mathrm{C}$ did not show any appreciable change in the mineralogy phases where the minerals retain their crystal phases. At temperature $650^{\circ} \mathrm{C}$, peaks representing kaolinite and illite started to decay and so did the peak of montmorillonite but at a lower rate. All peaks of clay minerals approximately disappeared when the investigated soils were heated up to $850^{\circ} \mathrm{C}$. Only peaks of non-clay minerals still exist. This gradual change in the peaks representing clay minerals is an evidence of the transition to the amorphous phase that took place due to the thermal treatment. It is to be noted that the soil (S1) had the highest amorphous phase, so it was a candidate to have the highest pozzolanic activity.

\subsection{Pozzolanic activity}

\subsubsection{Modified Chapelle test}

The principle of this test depends on determination of the amount of calcium hydroxide $\mathrm{Ca}(\mathrm{OH})_{2}$ that can be fixed by the thermally treated clay. The amount of $\mathrm{CH}$ fixed by the thermally treated clay can be calculated using the following formula:

$$
\mathrm{Ca}(\mathrm{OH})_{2}=2 \times \frac{V_{1}-V_{2}}{V_{1}} \times \frac{74}{56} \times 1000
$$

where $V_{1}$ is the volume of $\mathrm{HCl}$ needed to react with $\mathrm{CH}$ (without thermally treated clay) and $V_{2}$ is the volume of
$\mathrm{HCl}$ needed to react with $\mathrm{CH}$ (with thermally treated clay). French Standard [14] requires the amount of $700 \mathrm{mg}$ as a minimum level to consider the pozzolanic activity of the tested material acceptable.

Figure 6 shows the results of the modified Chapelle test for all the investigated clayey soil before and after the thermal treatment. As shown in Figure 6, the soil (S1), which demonstrated the highest amorphous phase in the XRD analysis, gave the highest number of pozzolanic activity $(745 \mathrm{mg})$ when heated up to $850^{\circ} \mathrm{C}$. This value exceeded the acceptable limit $(700 \mathrm{mg})$ specified by $\mathrm{NF}$ P18-513 [14]. The clayey soils S2 and S3 even when heated up to $850^{\circ} \mathrm{C}$ had values of relatively lower than $700 \mathrm{mg}$. As the strength required for soil application is relatively lower than that for structural concrete, the obtained pozzolanic activity numbers can be considered satisfactory.

\subsubsection{Compressive strength test method}

Results of compressive strength test conducted on cubic mortar samples are presented in Table 4. The cubic mortar sample was prepared by mixing clay thermally treated at $850^{\circ} \mathrm{C}$ for 3 hours with lime and standard sand. They were tested after curing for 2, 7 and 28 days. The results revealed the development of strength over time. This strength development can be attributed to the pozzolanic reaction between the glassy phase in the thermally treated clay and the lime. This reaction leads to formation of cementitious phases [6]. The strength development gives an evidence on the efficiency of thermal treatment of the three soil samples. It is worthwhile to mention that the results of the compressive strength test had a trend similar to that of modified Chapelle test. For instance, soil (S1) exhibited - when thermally treated at $850^{\circ} \mathrm{C}$ for 3 hours - the best number of pozzolanic activity and the highest compressive strength. Soil S2, by contrast, had the lowest number of pozzolanic activity and the lowest compressive strength when thermally treated at the same temperature.

\subsection{Atterberg limits}

Table 5 presents the results of PI of the clay soil mixtures. The decrease in PI values indicates the improvement of soil workability. As shown in Table 5, the three soils showed a significant decrease in PI when the lime was added by $6 \%$. A similar behaviour was reported in the literature for soils with the same classification $[4,6]$. This improvement could be attributed to the flocculation and 


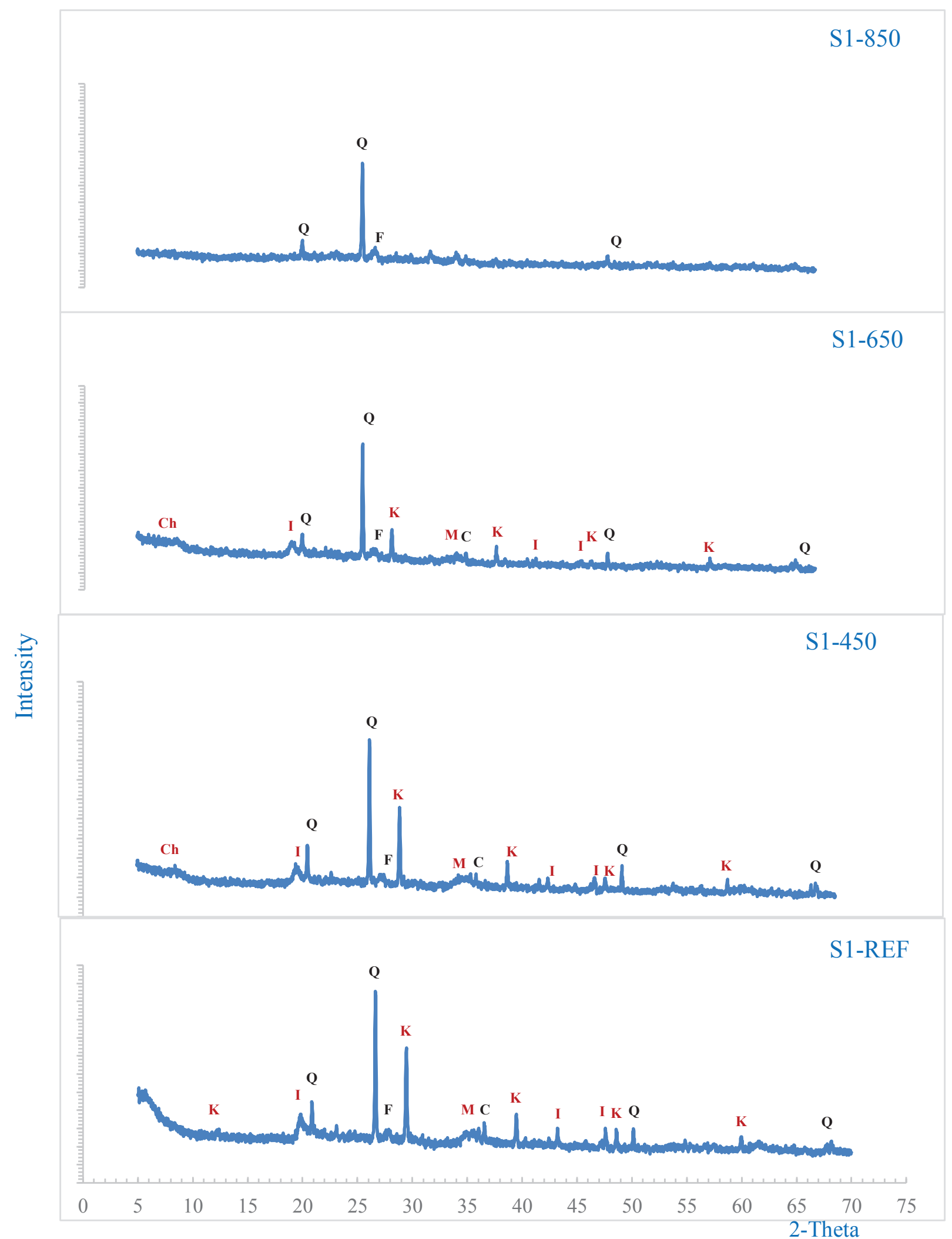

Figure 3: XRD analysis of the soil S1 before and after the thermal treatment (I: illite; Q: quartz; M: montmorillonite; K: kaolin; F: feldspar; C: calcite; Ch: chlorite). 


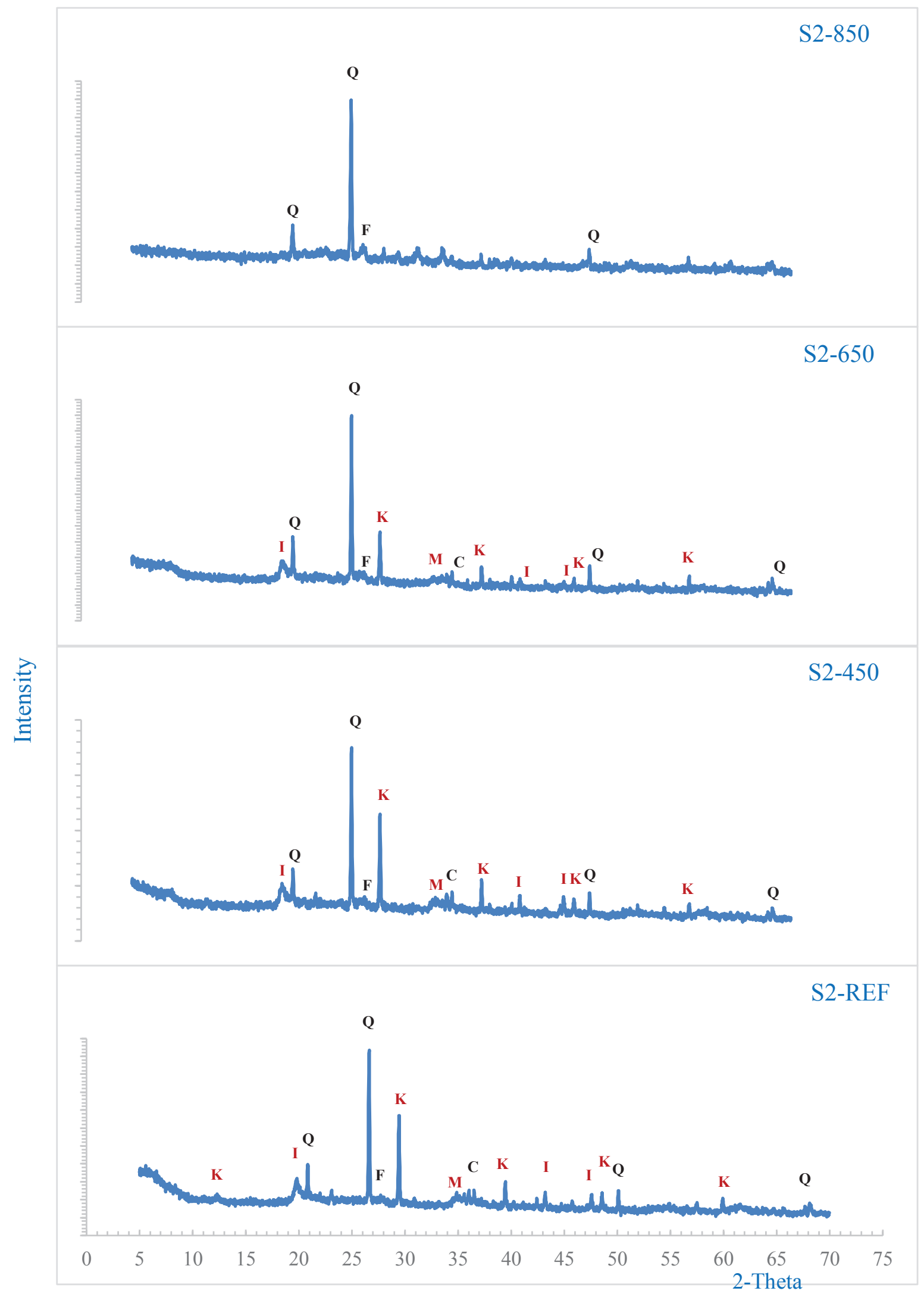

Figure 4: XRD analysis of the soil S2 before and after the thermal treatment (I: illite; Q: quartz; M: montmorillonite; K: kaolin; F: feldspar; C: calcite). 


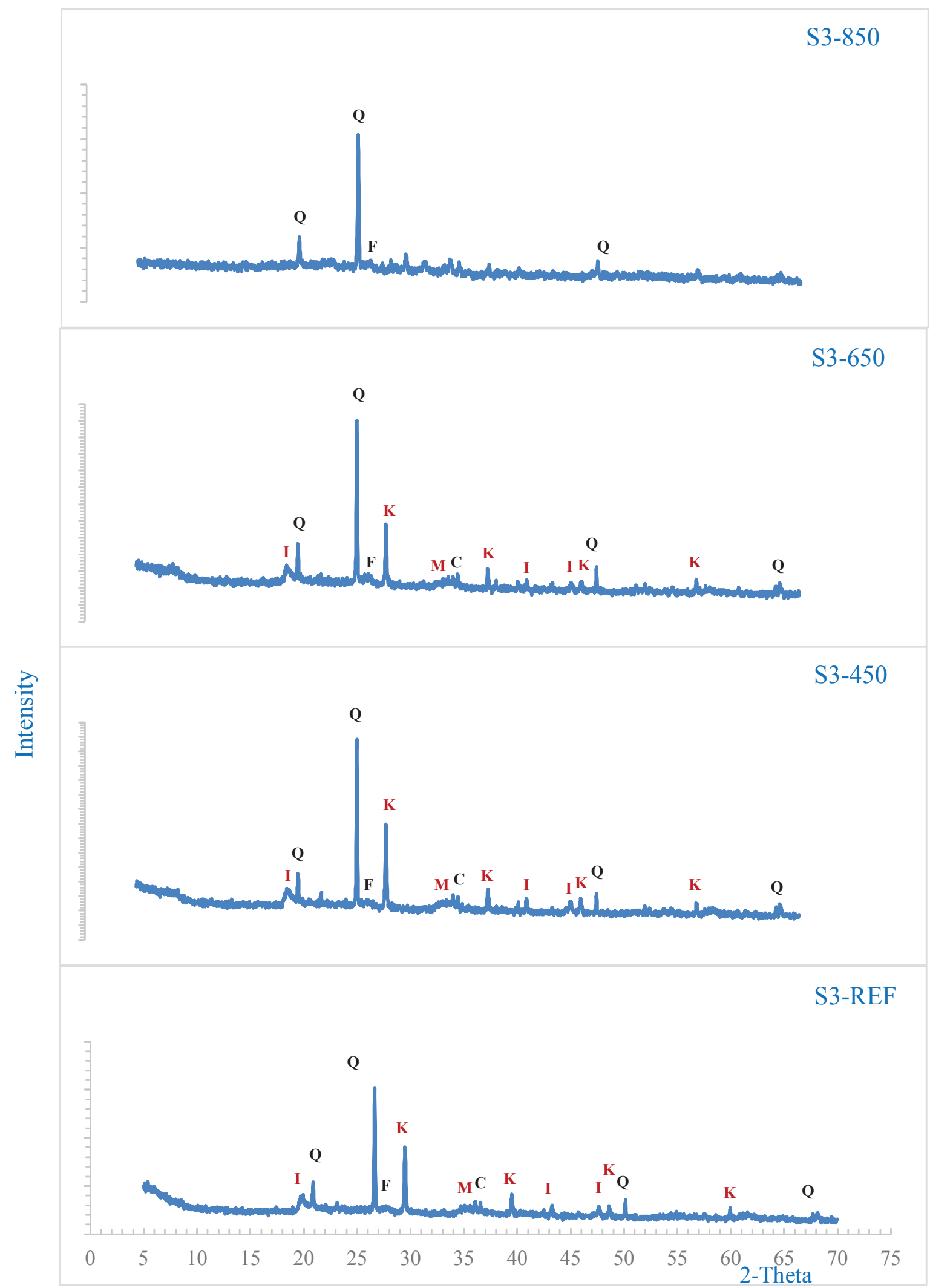

Figure 5: XRD analysis of the soil S3 before and after the thermal treatment (I: illite; Q: quartz; M: montmorillonite; K: kaolin; F: feldspar; C: calcite). 
Table 4: Compressive strength of clay mortar cubes cured for 2, 7 and 28 days.

\begin{tabular}{llll}
\hline \multicolumn{4}{l}{ Compressive strength $(\mathbf{M P a})$} \\
Clay soils & 2 days & 7 days & 28 days \\
\hline Soil 1 & 2.64 & 6.73 & 11.93 \\
Soil 2 & 2.80 & 5.23 & 8.45 \\
Soil 3 & 2.35 & 5.36 & 9.86 \\
\hline
\end{tabular}

Table 5: Atterberg limits of the studied mixtures.

\begin{tabular}{llll}
\hline Soil mixture designation & \multicolumn{2}{l}{ PI (\%) } \\
& S1 & S2 & S3 \\
\hline CC0L0 & 29 & 35 & 42 \\
CC0L6 & 9 & 6 & 7 \\
CC10L0 & 19 & 21 & 19 \\
CC20L0 & 14 & 17 & 16 \\
CC10L6 & 7 & 5 & 6 \\
CC20L6 & 4 & 3 & 4 \\
\hline
\end{tabular}

Table 6: Maximum dry unit weight $\gamma_{\mathrm{dmax}}$ and optimum water content $\mathrm{W}_{\mathrm{opt}}$ of the clay mixtures.

\begin{tabular}{lllllll}
\hline $\begin{array}{l}\text { Clay } \\
\text { mixture }\end{array}$ & \multicolumn{2}{c}{$\gamma_{\text {dmax }}\left(\mathbf{g} / \mathbf{c m}^{3}\right)$} & \multicolumn{5}{l}{$\boldsymbol{W}_{\text {opt }}(\%)$} \\
S1 & S2 & S3 & S1 & S2 & S3 \\
\hline CC0L0 & 1.48 & 1.38 & 1.30 & 25.5 & 23 & 27 \\
CC0L6 & 1.29 & 1.17 & 1.12 & 32.1 & 29.75 & 34.21 \\
CC10L0 & 1.52 & 1.51 & 1.36 & 24.32 & 21.6 & 24.75 \\
CC20L0 & 1.67 & 1.65 & 1.56 & 23.51 & 19.18 & 23.89 \\
CC10L6 & 1.39 & 1.31 & 1.27 & 28.68 & 25.88 & 30.11 \\
CC20L6 & 1.49 & 1.43 & 1.33 & 27.08 & 24.45 & 29.87 \\
\hline
\end{tabular}

aggregation of colloidal clay particle when the lime was added. The addition of thermally treated clay enhances the workability as a result of a reduction in the plasticity of the soils. The addition of thermally treated clay to the three soils had reduced the PI by about 30\% and 50\% when added at percentages of $10 \%$ and $20 \%$, respectively. However, the combination of $20 \%$ thermally treated clay and $6 \%$ lime exhibited the highest influence when the PI is concerned.

\subsection{Compaction test results}

The compaction test was used to evaluate the effect of adding thermally treated clay on $W_{\text {opt }}$ and $\gamma_{\text {dmax }}$ of the investigated clay soils. Table 6 presents the effect of adding

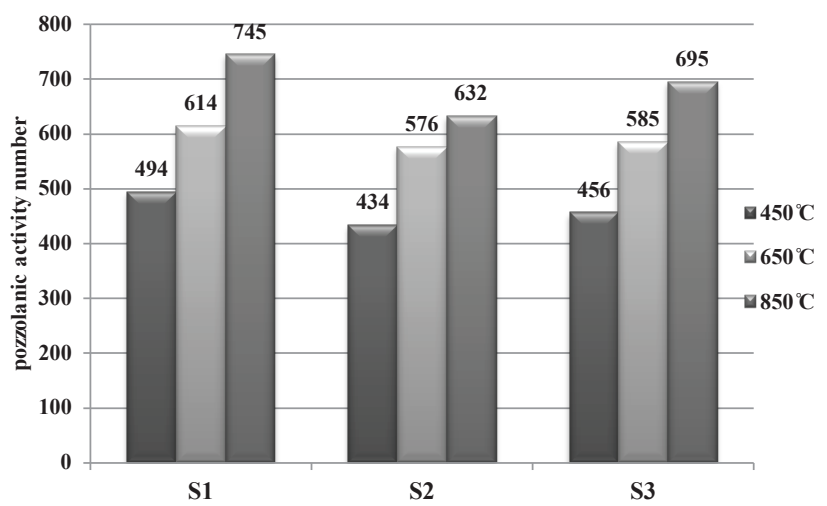

Figure 6: Pozzolanic activity numbers of clay soils treated at different temperatures.

thermally treated clay, lime and their combinations on the compaction properties of the studied soils. It can be clearly seen that adding lime alone to the three soils decreased $\gamma_{\text {dmax }}$ and increased $W_{\text {opt }}$. This can be attributed to the lower specific gravity of lime and the higher water retention property of lime, when compared with those of soils [6]. Adding thermally treated clay alone caused a decrease in $W_{\text {opt }}$ and an increase in $\gamma_{\text {dmax }}$ with the increase in thermally treated clay content. This can be due to the lower affinity to water and the higher specific gravity of thermally treated clay when compared to those of the natural soil. The combination of lime and thermally treated clay kept the values of the optimum water content $W_{\text {opt }}$ and the maximum dry unit weight $\gamma_{\text {dmax }}$ around their values in the initial soils as shown in Table 6.

\subsection{Free swelling and swelling pressure}

Generally, swelling potential has been used to describe the ability of a soil to swell, in terms of volume change or the pressure required to prevent swelling [20]. In the oedometer device, the swelling occurs in one dimension due to the confining effect in the device ring. Free swell is defined as the percentage increase in height in relation to the original height, while swelling pressure represents the pressure required to prevent swelling.

The results of free swelling and swelling pressure are illustrated in Table 7. The untreated soils showed the higher values of free swelling and swelling pressure. They ranged from $(8.4 \%)$ to $(10.6 \%)$ after 96 hours. This free swelling was restricted, and the swelling pressure was reduced when $10 \%$ and $20 \%$ thermally treated clay were added to the soil mixture. Further restriction and pressure reduction were observed when $6 \%$ lime was added to 
Table 7: Values of free swelling and swelling pressure versus the combinations of soil and stabilisers (calcined clay and lime).

\begin{tabular}{lllllll}
\hline Clay mixture & $\begin{array}{l}\text { Soil } 1 \\
\text { Free swell (\%) }\end{array}$ & $\begin{array}{l}\text { Swelling pressure } \\
(\mathbf{k P a})\end{array}$ & $\begin{array}{l}\text { Soil } \mathbf{2} \\
\text { Free swell (\%) }\end{array}$ & $\begin{array}{l}\text { Swelling pressure } \\
(\mathbf{k P a})\end{array}$ & $\begin{array}{l}\text { Soil 3 } \\
\text { Free swell (\%) }\end{array}$ & $\begin{array}{l}\text { Swelling pressure } \\
(\mathbf{k P a})\end{array}$ \\
\hline CCOL0 & 8.35 & 80 & 9.24 & 125 & 10.55 & 150 \\
CCOL6 & 2.56 & 40 & 2.65 & 35 & 2.16 & 35 \\
CC10L0 & 5.85 & 75 & 8.56 & 100 & 7.12 & 110 \\
CC20L0 & 4.17 & 60 & 4.85 & 65 & 3.92 & 60 \\
CC10L6 & 1.75 & 25 & 1.66 & 20 & 1.19 & 20 \\
CC20L6 & 1.44 & 10 & 1.12 & 5 & 0.88 & 5 \\
\hline
\end{tabular}

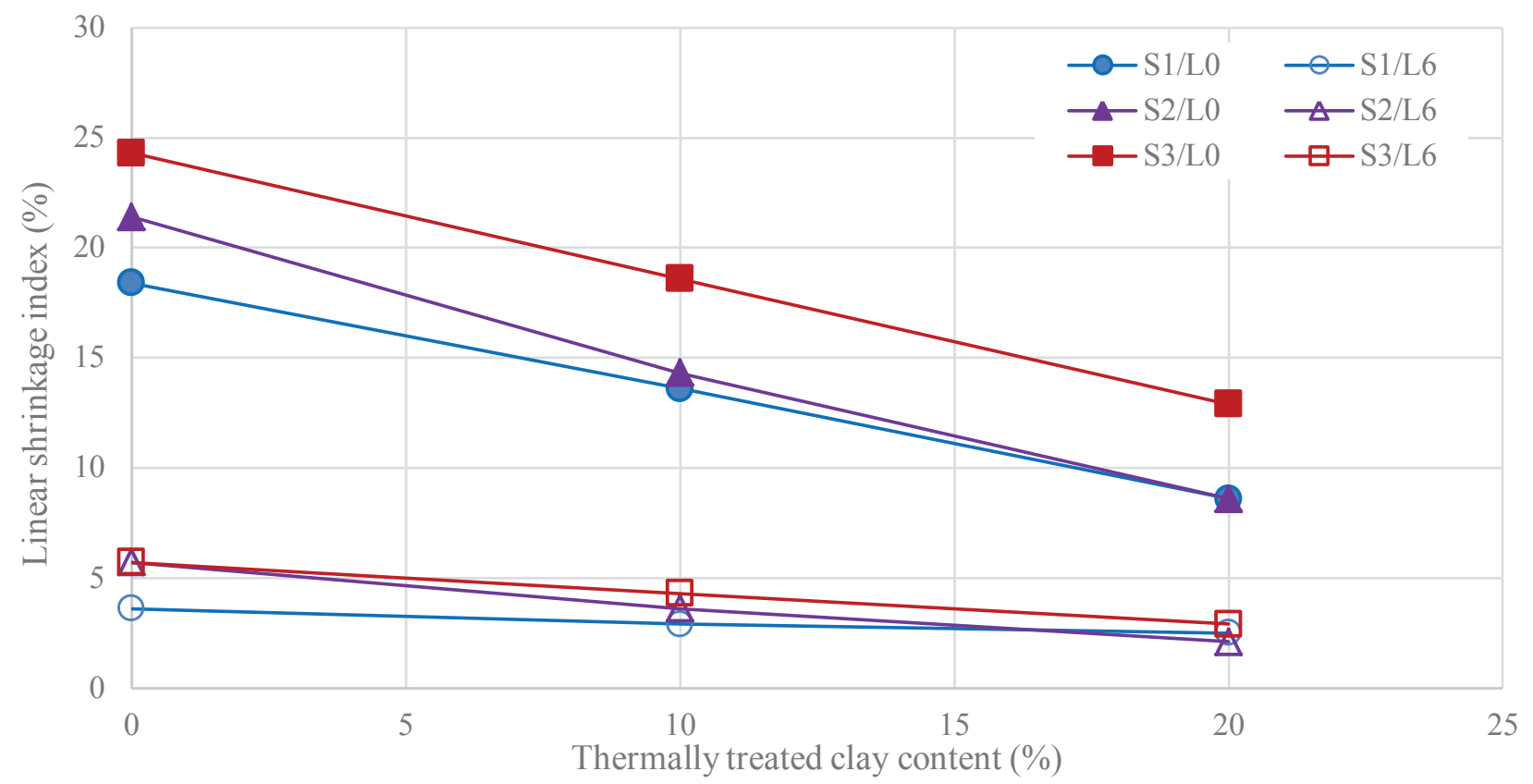

Figure 7: Linear shrinkage index values of the soil mixtures.

the soil mixtures. The best result was obtained when thermally treated clay and lime were added at $20 \%$ and $6 \%$, respectively.

\subsection{Linear shrinkage index}

Linear shrinkage index can be defined as the ratio of decrease in linear dimension of a sample to its initial dimension, eq (1). It is expressed in (\%) and is given by the nearest whole number [21]. The linear shrinkage test was conducted on elongated clayey soil samples to measure shrinkage deformation when the samples were placed in a brass mould and dried in an oven for 24 hours at a temperature of $105^{\circ} \mathrm{C}$. The results are displayed in Table 8 and Figure 7. As shown in Figures 7 and 8, a significant reduction in linear shrinkage was observed when the lime was added by $6 \%$. This reduction can be attributed to the chemical reactions between lime and clay [22]. Adding thermally treated clay alone had also caused a positive effect, particularly when added at $20 \%$ clay replacement. Its linear shrinkage index was reduced by a half when compared with that of the untreated soil. The lowest strain was attained in the mixture CC20L6, which can be considered as non-problematic [22].

\subsection{Microstructural investigation}

Three soil 2 samples, i.e. CCOLO, CC2OL0 and CC20L6, were prepared and cured for 7 days. Fragments of these samples dried, broken off and washed with acetone were examined and analysed by SEM and EDX techniques. Figures 9-11 show the SEM micrographs and EDX analysis at different 


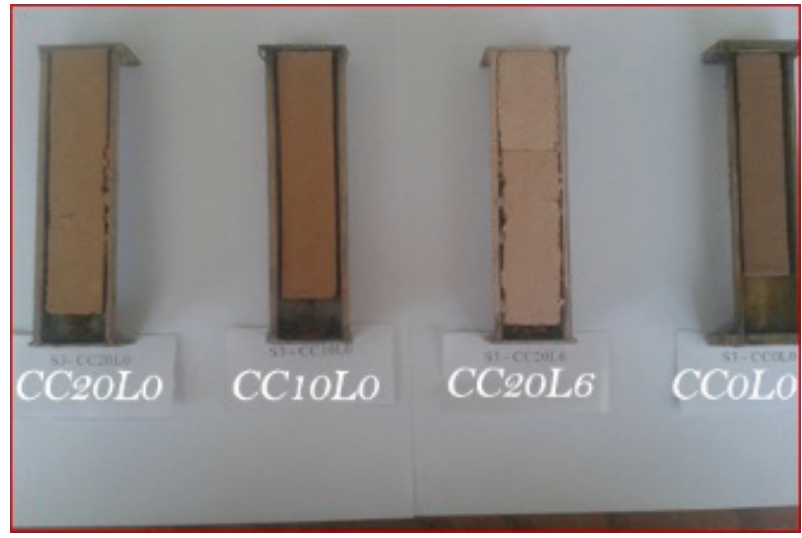

Figure 8: Photograph of soil S3 (some untreated and treated samples).

Table 8: Linear shrinkage values of the investigated clay mixtures.

\begin{tabular}{llll}
\hline Clay mixture & \multicolumn{3}{c}{ Linear shrinkage (LSI\%) } \\
& Soil 1 & Soil 2 & Soil 3 \\
\hline CC0L0 & 16.46 & 21.4 & 24.3 \\
CC0L6 & 13.63 & 14.3 & 18.6 \\
CC10L0 & 10.06 & 8.6 & 12.9 \\
CC20L0 & 3.64 & 5.7 & 5.7 \\
CC10L6 & 2.93 & 3.6 & 4.3 \\
CC20L6 & 2.57 & 2.1 & 2.9 \\
\hline
\end{tabular}

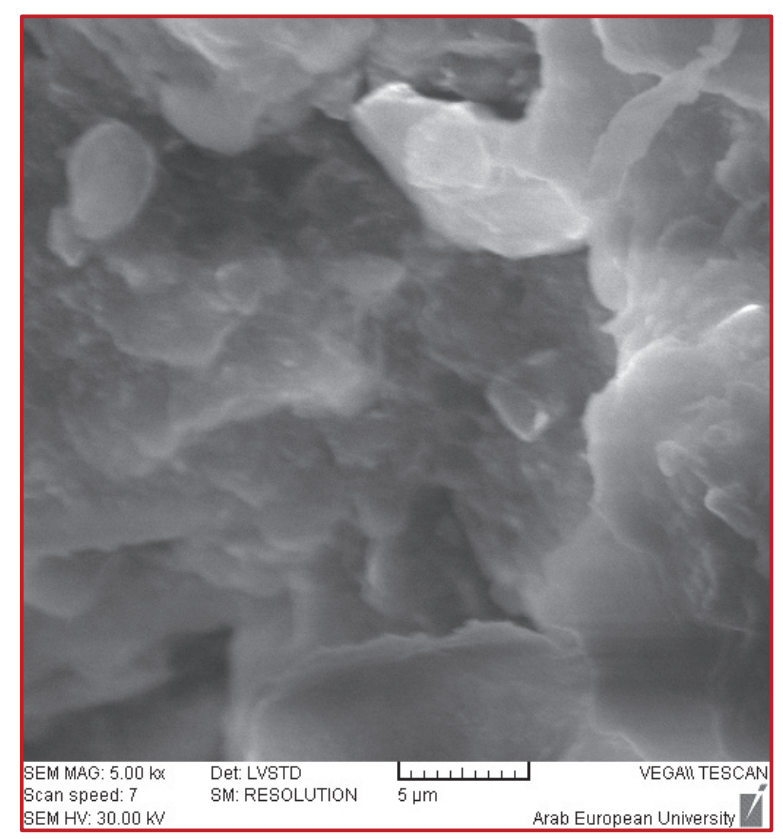

locations of the studied samples. As shown in Figure 9, the natural soil 2 has a discontinuous structure as no hydration products exist. The EDX analysis showed Si and $\mathrm{Al}$ as the main elements in the natural clay. However, it is clearly seen from Figures 10 and 11 that the microstructure of the clayey soil was significantly modified when either mixed with thermally treated clay or lime-thermally treated clay and cured for 7 days. It could be observed in Figure 11 that cementing materials such as C-A-S-H were formed. This observation is consistent with that reported by Al-Swaidani et al. [6] and Chaunasli and Peethamparan [23]. This indicated that a pozzolanic reaction had taken place between $\mathrm{CaO}$ present in lime and $\mathrm{SiO}_{2}$ and $\mathrm{Al}_{2} \mathrm{O}$ in the soil and thermally treated clay. Hence, improved properties obtained when adding thermally treated clay and lime could be mainly attributed to these cementing materials.

\section{Conclusion}

Effect of adding thermally treated clay to the natural expansive clay soil has been studied. Consistency, compaction, swelling and linear shrinkage have particularly been investigated. Pozzolanic activity of the thermally treated clay has been measured as well. Based

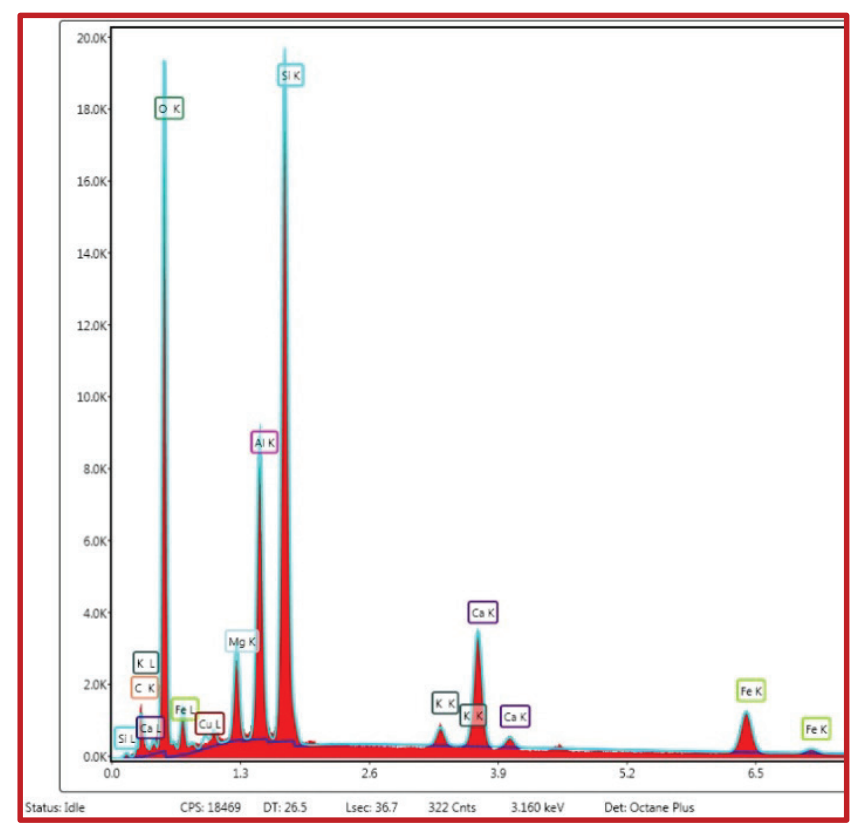

Figure 9: SEM micrograph and EDX analysis of natural soil 2 cured for 7 days. 

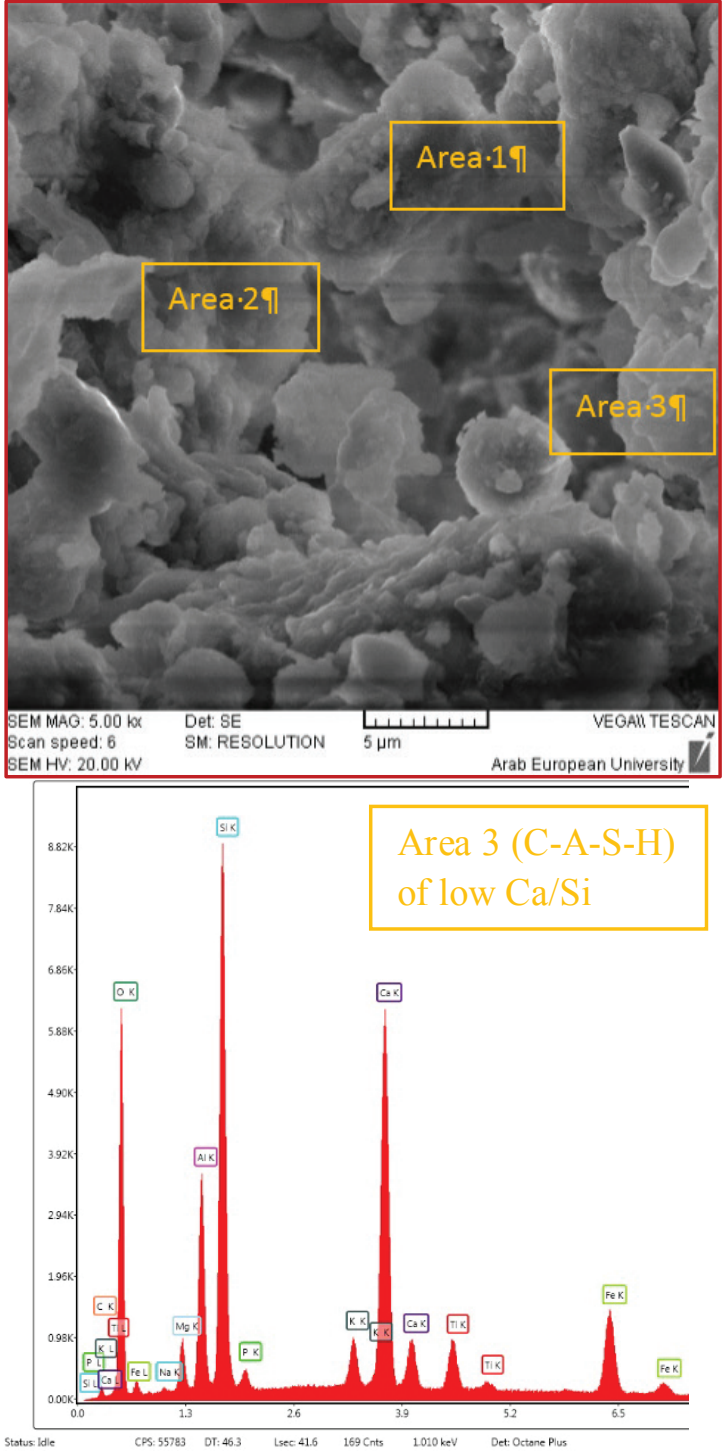
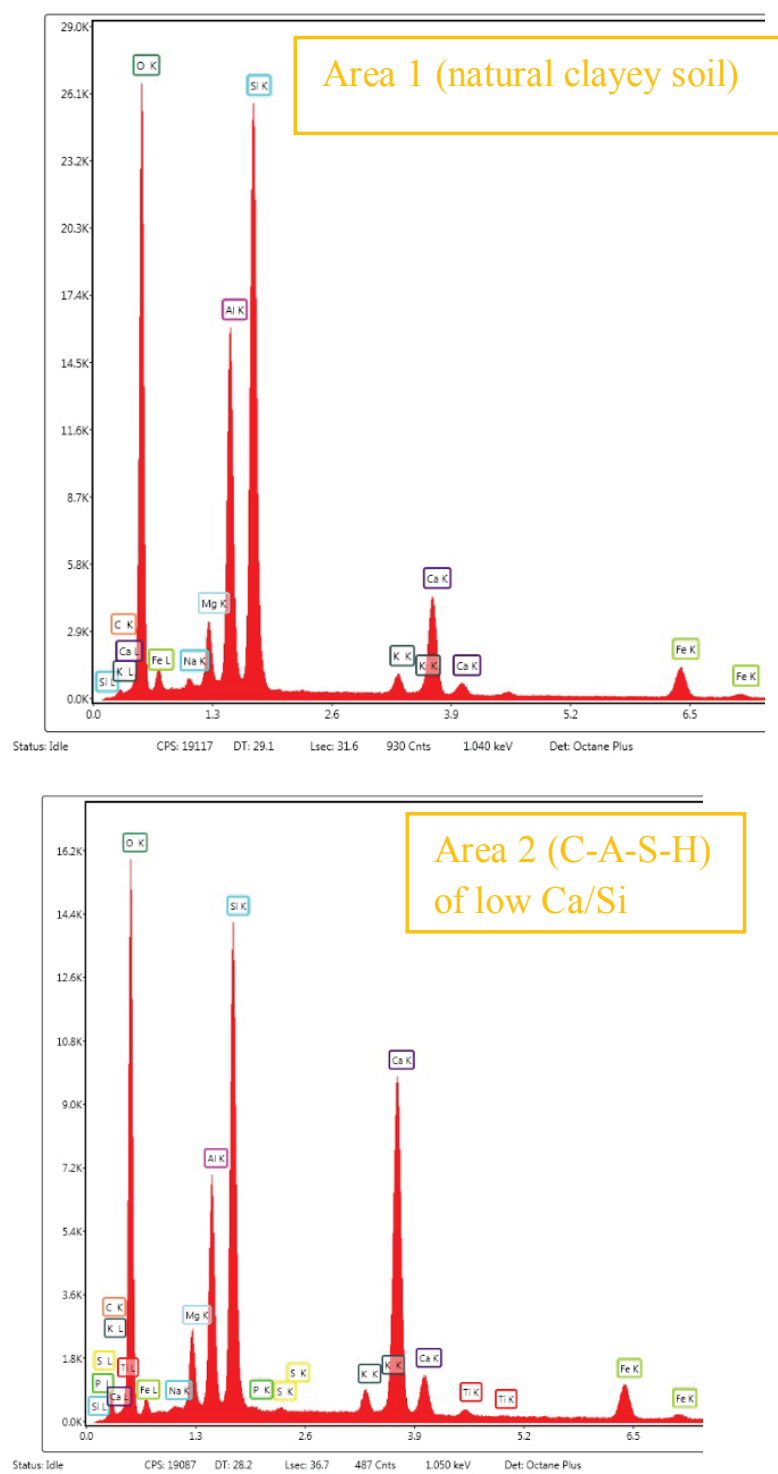

Figure 10: SEM micrograph and EDX analysis of CC20L0 mixture (soil 2) cured for 7 days.

on the results obtained, the following conclusions can be drawn:

1. PI decreased with increasing thermally treated clay content.

2. Adding thermally treated clay decreased $W_{\text {opt }}$ and increased $\gamma_{\text {dmax }}$.

3. Use of thermally treated clay alone led to a reduction in swelling pressure of the natural clay soil. Further reduction was also observed when the lime was added.
4. A significant reduction in the linear shrinkage strains was noted when $20 \%$ thermally treated clay and $6 \%$ lime were added together.

5. The thermal treatment at $850^{\circ} \mathrm{C}$ showed a significant transformation in the studied clay from the crystalline to the amorphous phase. This was confirmed by the modified Chapelle test, where the highest pozzolanic activity was noted in the samples treated at this temperature level.

6. SEM and EDX analysis confirmed that the addition of either thermally treated clay or both thermally treated 

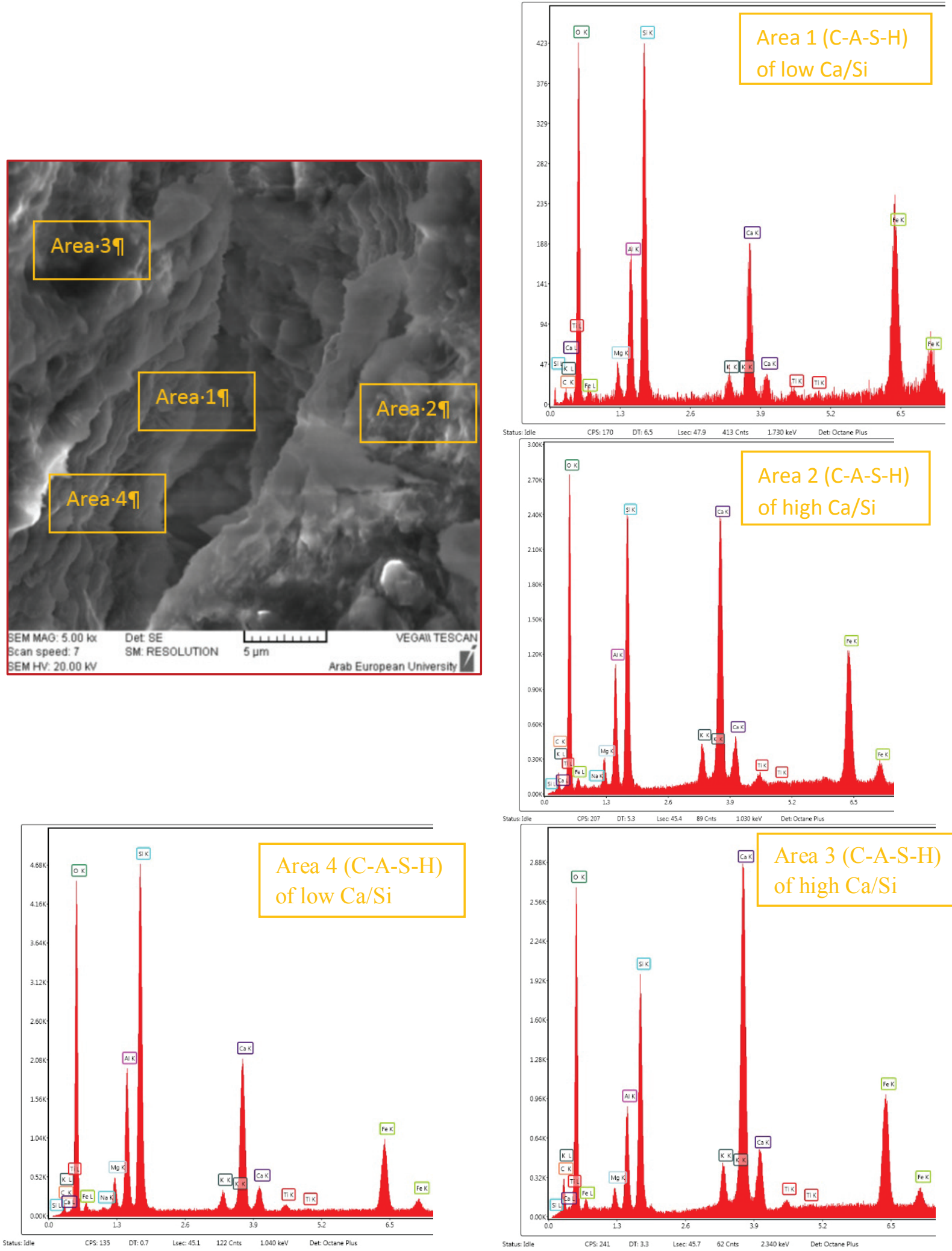

Figure 11: SEM micrograph and EDX analysis of CC20L6 mixture (soil 2) cured for 7 days. 
clay and lime to the investigated clayey soil has caused a marked change in morphology. The results showed presence of C-S-H and C-S-A-H in both additions. These cementitious phases induced significant improvements in the engineering properties of the investigated clayey soil.

7. Thermal treatment of the natural expansive clay soil could be considered as a promising approach. Adding thermally treated clay as partial replacement of clay can improve the geotechnical properties of the natural clay soil and save natural sources.

8. Further study to investigate the effects of adding thermally treated clay on other geotechnical properties of expansive clay soils such as California Bearing Ratio (CBR) and shear strength is highly recommended.

Conflict of interest: The authors declare that there are no conflicts of interest associated with this paper.

\section{References}

[1] Mallela, J., Harold Von Quintus, P., Smith, K.L. (2004). Consideration of Lime-Stabilized Layers in MechanisticEmpirical Pavement Design. The National Lime Association, Arlington, VA, USA

[2] Firoozi Akbar, A., Olgun, C., Firoozi Asghar, A., Baghini, S. M. (2017). Fundamentals of soil stabilization. International Journal of Geo-Engineering, 8(26), 16. doi: 10.1186/s40703-017-00649.

[3] Harichane, K., Ghrici, M., Khebizi, W., Missoum, H. (2010). Effect of the combination of lime and natural pozzolana on the durability of clayey soils. EJGE, 15, 1194-1210.

[4] Harichane, K., Ghrici, M., Missoum, H. (2011). Influence of natural pozzolana and lime additives on the temporal variation of soil compaction and shear strength. Front Earth Science, 5(2): 162-169. doi: 10.1007/s11707-011-0166-1.

[5] Zoubir, W., Harichane, K., Ghrici, M. (2013). Effect of lime and natural pozzolana on dredged sludge engineering properties. EJGE, 18, 589-600.

[6] Al-Swaidani, A., Hammoud, I., Meziab, A. (2016). Effect of adding natural pozzolana on geotechnical properties of lime-stabilized clayey soil. Journal of Rock Mechanics and Geotechnical Engineering, 8(5), 714-725. doi: 10.1016/j. jrmge.2016.04.002.

[7] EN 197-1:2000. (2000). Composition Specifications and Conformity Criteria for Common Cements. European Committee for Standardization, Brussels, Belgium.

[8] Al-Rawas, A.A., Hago, A.W., Al Lawati, D., Al Battashi, A. (2001). The Omani artificial pozzolans (Sarooj). Cement and Concrete Aggregates, 32(1), 19-26. doi: 10.1520/CCA10521).
[9] Shvarzman, A., Kovler, K., Schamban, I., Grader, G., Shter, G. (2002). Influence of chemical and phase composition of mineral admixtures on their pozzolanic activity. Advances in Cement Research, 14(1), 35-41. doi: 10.1680/adcr.2002.14.1.35.

[10] Souri, A., Golestani-Fard, F., Naghizadeh, R., Veiseh, S. (2015). An investigation on pozzolanic activity of Iranian kaolins obtained by thermal treatment. Applied Clay Science, 103, 34-39. doi: 10.1016/j.clay.2014.11.001.

[11] Rashad, A.M. (2013). Metakaolin as cementitious material: history, source, production and composition-a comprehensive review. Construction and Building Materials, 41, 303-318. doi: 10.1016/j.conbuildmat.2012.12.001.

[12] Massazza, F. (1993). Pozzolanic cements. Cement and Concrete Composites, 15, 185-214. doi:10.1016/0958-9465(93)90023-3.

[13] ASTM D 2487. (2011). Standard Practice for Classification of Soils for Engineering Purposes (Unified Soil Classification System). ASTM International, West Conshohocken, PA, USA.

[14] NF P18-513. (2010). Métakaolin, addition pouzzolanique pour bétons: Définitions, spécifications, critères de conformité. AFNOR, France.

[15] ASTM D 4318. (1993). Standard Test Method for Aterberg Limits. ASTM International, West Conshohocken, PA, USA.

[16] ASTM D 698. (2000). Standard Test Method for Laboratory Compaction Characteristics of Soils. ASTM International, West Conshohocken, PA, USA.

[17] ASTEM D 4645. (2000). Standard Test Methods for OneDimensional Swell or Settlement Potential of Cohesive Soils. ASTM International, West Conshohocken, PA, USA.

[18] ASTM D 2435. (2000). Test Method for One-Dimensional Consolidation Properties of Soils. ASTM International, West Conshohocken, PA, USA.

[19] BS 1377: part 2. (1990). Methods of Test for Soils for Civil Engineering Purposes - Part 2: Classification Tests. British Standards Institute, London, UK.

[20] Gueddouda, M.K., Goual, I., Lamara, M., Mekarta, B. (2011). Chemical stabilization of expansive clays from Algeria. Global Journal of Researches in Engineering, 11(5), 1-7.

[21] Rao, SM. (2006). Identification and classification of expansive soils. In: Expansive Soils-Recent Advances in Characterization and Treatment. Edited by A.A Al-Rawas, M.F.A Goosen. Taylor and Francis Group, London, UK, pp. 15-24.

[22] Kariuki, P.C., Shepherd, K., van der Meer, F. D. (2006) Spectroscopy as a tool for studying swelling soils. In: Expansive Soils-Recent Advances in Characterization and Treatment. Edited by A.A. AlRawas, M.F.A. Goosen. Taylor and Francis Group, London, UK, pp. 15-24.

[23] Chaunasli, P., Peethamparan, S. (2010). Microstructural and mineralogical characterization of cement kiln dust activated fly ash binder. Transportation Research Board, 2164, 36-45. doi: 10.3141/2164-05 